\title{
A Literary Exploration of Existential Feminism in the Novella The Moon Opera Through the Application of Intertextuality Theory
}

\author{
Ruixi Yan ${ }^{1}$ \\ ${ }^{1}$ Nanjing Foreign Language School, Nanjing, China \\ Correspondence: Ruixi Yan, Nanjing Foreign Language School, Nanjing, Jiangsu, China. E-mail: \\ Amber1350@126.com
}

Received: November 20, 2021

Accepted: December 18, 2021

Online Published: December 22, 2021

doi:10.20849/ajsss.v6i5.964

URL: https://doi.org/10.20849/ajsss.v6i5.964

\begin{abstract}
Second-wave feminism was a period of feminist activity that began in the early 1960s in the western world, which focused on criticizing the patriarchal institutions or cultural practices throughout the society. Originating several centuries earlier, Chinese opera culture has been ahead of its time in demonstrating the male-dominated society's oppression against women. As one of the principal founders of second-wave feminism, Simone de Beauvoir's classical feminist theory in her book, The Second Sex, mainly introduced the sex-gender distinction. In this article, the author aims to reveal how Bi Feiyu, the writer of The Moon Opera, successfully conveyed existential feminist ideas, especially Beauvoir's famous assertion that "one is not born but becomes a woman", through his careful selection of the art type Qing Yi (Qingyi is the main woman role in Peking Opera and often plays dignified, serious, and decent characters, which are mostly wives or mothers undergoing severe ordeal) and the portrayal of two generations of Qing Yi performers. In the process of analysis, the author not only examined Bi Feiyu's application of intertextuality theory, but also derived conclusions from other mainstream feminist thoughts such as the feminist theory of the dressed female body and the transactional sex theory.
\end{abstract}

Keywords: existential feminism, intertextuality theory, Peking Opera, feminist theory of the dressed female body, transactional sex

\section{Introduction}

The Moon Opera, a novella written by Bi Feiyu, tells the story of a Peking Opera actress Xiao Yanqiu in interposed narration. She was once famous for playing Chang'e in theatre but ended up ruining her career with her own hands. After 20 years of leaving the stage, she has made every effort to return to perform her signature show again, one of the most famous pieces of classical Peking Opera, Flying To The Moon. As a male writer, Bi Feiyu has always kept a close eye on the livelihoods of female artists. He composed The Moon Opera from the view of a bystander to trigger readers' thoughts about human nature.

\section{The Application of Intertextuality Theory in the Novel}

When the author read the text, mythological stories and scenes of opera performances often came to the author's mind. Such association beyond control is based on the successful application of intertextuality theory throughout the entire book. While it's a brand new literary theory coming up in the 20th century defined in both broad and narrow sense, the author chooses to adopt the broader interpretation by Barthes and Kristeva in this article, which defines intertextuality as the relationship between any text and the combination of knowledge, codes and ideational practices that have given meaning to the text.

But since The Moon Opera is written in Chinese, the author would pay more attention to a further interpretation offered by the Chinese scholar Cheng Xilin, who proposed to classify the embodiment of intertextuality theory in Chinese literature in five different ways. The author came to observe that one of them was specifically applied in this book, namely the imperceptible influences of the ubiquitous traditional Chinese culture.

Following his perspective, the author hopes to materialize the so-called "untraceable" cultural tradition in the form of Peking Opera and to explore the plight of women's survival in the long-standing Chinese culture.

\section{The Marginalization of Female Characters in Chinese Opera Culture}

As introduced in the text, Qingyi requires a plaintive high-pitched singing style that sounds nearly "out of 
breath", which is closely related to the fact that Qingyi characters are often virtuous wives and mothers experiencing extreme suffering beyond endurance. In the feudal society of ancient China, women were mostly dependent on men and viewed as mere appendages who could not rely on themselves.

Therefore, the image of Qing Yi normally as women who would remain loyal to their husbands even after being abandoned actually suggests those male opera creators' expectations of women. Thus, all these tragic Qing Yi roles are indeed a reminder of women's passive and lowly status in ancient Chinese literature. Furthermore, according to the feminist theory of the dressed female body, women's dress code is a projection of the dominant ideology of a society. Since the costume of Qing Yi's roles is mostly plain, and the performances are extremely feminine, it indicates that males in ancient China must have wanted to gain entire control of the females by setting mildness and fragility as the common standard for a typical woman. In conclusion, viewing Qingyi as the so-called "touchstone of femininity", which is routine in ancient China, would only reduce the diversity of women and regulate them under the male gaze. This also verified Beauvoir's hypothesis that woman is a historical-cultural product, rather than determined or a natural species.

As opposed to Qing Yi is the painted-face role "Tong Chui Hua Lian" ("Tong Chui Hua Lian" is for "rough" or "mighty" male characters that require heavy face painting), which is only hastily mentioned in the text. Based on the content of the novel, the owner of the theatre believes a play whose emphasis is a female character will bring bad luck to the audience, so it's necessary to add "Tong Chui Hua Lian" as a male role symbolizing masculinity in the performance of Flying To The Moon.

Such a superstitious assertion further reflects the arrogance of men in power and their disdain for women. In fact, the design of the "Tong Chui Hua Lian" in the plot by Bi Feiyu could be interpreted as a symbol of the patriarchal society in general, which also indicates that women, as a vulnerable minority, could never save themselves from the oppression of males despite their efforts to resist.

\section{Sex Exploitation of Female Artists}

In addition to the focus on Peking Opera art itself, Bi Feiyu gave a deeper meaning to his work by setting up the tragic destiny of female opera performers.

Starting with Liu Ruobing as the first generation of Qingyi, who used to be the most popular beauty in her times, sadly becomes "as ugly as a demon" after the Cultural Revolution. However, what hurts the readers most is not the decay of her appearance, but rather what a deputy commander as one of her old-time fans said, "You can't make yourself dirty just for the sake of sleeping with a once-famous woman". The utmost statement tramples on women's dignity, and demonstrates how men easily objectify women as worthless lust dolls after they gain enough power, even for the dream girls they once worshiped and loved.

On the other hand, the second generation of Qing Yi, Xiao Yanqiu, also faces the dilemma of losing her voice in a male-dominated society. To gain a robust restart of her artistic career, Xiao Yanqiu willingly sells her own body to the theater investor. This kind of transaction has been "the same from ancient times to modern times", and a male in power with such sexual privilege could still act as if he's morally just and continue being "a great man". We could conclude that throughout the long history of patriarchal society, it has become a social norm that rich and powerful male rulers would dominate female bodies at will, while sacrificing flesh has become the inevitable price that powerless women have to pay to pursue their dreams. Therefore, when Xiao Yanqiu vaguely realizes that she is gradually "becoming a prostitute but just not in terms of the body", she is silently mourning the female dignity she has to give up for the sake of art in her subconscious.

\section{Conclusion}

Unlike traditional literary techniques that pursue clear interpretations of certain texts, intertextuality theory focuses more on semantic fluidity, which allows a piece of artwork to reflect the influences of a particular culture on its creator. By combining the Chinese opera culture with his book The Moon Opera, Bi Feiyu managed to diversify his novella's themes while demonstrating how women could be deeply harmed by the external environment in a patriarchal male-dominated society.

\section{References}

Cheng, X.-L. (1996). Overview of Intertextuality Theory. Foreign Literature, (1), 72-78. https://doi.org/10.16430/j.cnki.fl.1996.01.013

Culler, J. (1981). The Pursuit of Signs. Cornell University Press, pp. 103-104.

Gu, L.-L. (2021). The dilemma of Women's Growth and Narrative Presentation in Bi Feiyu's Novels. Fiction Review, (5), 201-207. 
Iser, W. (1993). Fiction and Imagination. Johns Hopkins University Press, pp. 1-21.

Kristeva, J. (1980). Desire in Language: A Semiotic Approach to Literature and Art. Oxford press: Blackwell.

Peng, X.-Y. (2018). The female figure in Bi Feiyu's novel. The Yangtze River Poetry Journal, (6), 109-112.

Stavro, E. (1999). The Use and Abuse of Simone de Beauvoir: Re-Evaluating the French Poststructuralist Critique. European Journal of Women's Studies, $263-280$. https://doi.org/10.1177/135050689900600302

Tyner, K. E., \& Ogle, J. P. (2009). Feminist Theory of the Dressed Female Body: A Comparative Analysis and Applications for Textiles and Clothing Scholarship. Clothing and Textiles Research Journal, 27(2), 98-121. https://doi.org/10.1177/0887302X08322715

Wu, J.-J. (2019). Contemporary Chinese Fiction's Borrowing from the Opera Genre. Shanghai International Studies University.

Zhang, N. (2018). Usage of opera elements in the novel The Moon Opera. Journal of Hubei Industrial Polytechnic, 31(3), 33-40.

Zhao, L.-Y. (2010). Bi Feiyu's Writing on Female Tragedy - Centering on The Moon Opera and Three Sisters. Literature and Art Forum, (7), 158-160.

\section{Copyrights}

Copyright for this article is retained by the author(s), with first publication rights granted to the journal.

This is an open-access article distributed under the terms and conditions of the Creative Commons Attribution license (http://creativecommons.org/licenses/by/4.0/). 